\section{Niewysłowiona wojna. Trauma i „kryzys języka" w angielskiej i niemieckiej literaturze pierwszej wojny światowej}

Martin Löschnigg racając pamięcią do okopów I wojny światowej, brytyjski pisarz Ford Madox Ford odnotowuje, że niekiedy było mu trudno znaleźć dla swoich wspomnień adekwatne wysłowienie:

Nawet teraz [...] wystarczy mi rzucić okiem na nazwy „Ploegsteert” czy „Armentières”, ażeby przed moimi oczami pojawiły się niezwykle żywe i dokładne obrazy [...] ludzi tryskających fontannami krwi i przemieniających się w błotnistą breję [...]. Gdy jednak przychodzi je opisać!... Otóż nie: myśl staje jak wryta, mózg odmawia posłuszeństwa i się wyłącza. ${ }^{1}$

W podobnym tonie wypowiadał się poeta i krytyk sztuki Herbert Read, który w swoim pamiętniku z czasów

1 F.M. Ford War Prose, ed. by M. Saunders, Carcanet, Manchester 1999, s. 37. Jeżeli w przypisie nie podano nazwiska tłumacza, to przekład jest mojego autorstwa [G.M.].

\author{
Martin Löschnigg - \\ profesor nadzwy- \\ czajny w Instytucie \\ Anglistyki na Uni- \\ wersytecie w Grazu. \\ Jego zainteresowania \\ badawcze obejmują \\ narratologię, auto- \\ biograficzność, lite- \\ raturę wojenną oraz \\ literaturę kanadyjską. \\ Ostatnio współre- \\ dagował dwie prace \\ zbiorowe: The Great \\ War in Post-Memory \\ Literature and Film \\ (wraz z Marzeną \\ Sokołowską-Paryż, \\ 2014) i North America, \\ Europe and the Cultu- \\ ral Memory of the First \\ World War (z Karin \\ Kraus, 2015).
}


wojny, noszącym wymowny tytuł The Contrary Experience [Odmienne doświadczenie], napisał, że żołnierzy od cywilów oddzielało coś na kształt „mrocznej przesłony utkanej z okropieństw i gwałtu: świadomość wojennych realiów. Przez tę przesłonę nie byłem się w stanie komunikacyjnie przebić. Nie potrafił tego zresztą żaden z moich przyjaciół, którzy przeżyli to co ja"². Po drugiej stronie parawanu również odczuwano, że żołnierze doświadczyli czegoś, co nie może być ujęte w słowa, a czego cywile nie są w stanie pojąć. $\mathrm{Z}$ tego powodu Vera Brittain zwraca uwagę w swoim Testament of Youth $[\mathrm{Te}-$ stamencie młodości], że „między mężczyznami i kobietami, które ci kochali” wojna postawiła „barierę niedającego się wysłowić doświadczenia. [...] Dosyć szybko dopuściłam myśl, że na drodze do porozumienia może stać jakaś niewzruszona zapora"3.

Literatura I wojny dostarcza bardzo wielu świadectw, iż żołnierze walczący na froncie mieli przytłaczające poczucie, że własnych przeżyć nie mogą opowiedzieć cywilom i że istnieje ogromna przepaść między ludźmi rzuconymi na front i zostającymi w domach. Z pewnością wygląda to na paradoks, szczególnie jeśli wziąć pod uwagę, jak wiele tekstów powstało pod wpływem wojny - pamiętników, powieści, dramatów, wreszcie zaś niezliczonych wierszy - i że jednocześnie wiele z tych tekstów bezpośrednio deklaruje, iż dzięki nim żyjący w nieświadomości cywile poznają "prawdę” o wojnie. Zarazem jednak topos głoszący, że okropieństwa wojny stanowią wyzwanie dla języka, przenika literaturę tamtego czasu, zaś przeświadczenie o istnieniu nieprzekraczalnej bariery między tymi, którzy byli i którzy (zwłaszcza kobiety) nie byli na froncie, urosło do rangi jednego z największych mitów związanych z wojną.

W niniejszym tekście chciałbym przebadać ów topos niemożności wysłowienia [unsayability] czy też przekazania bitewnych doświadczeń I wojny, odwołując się do teorii traumy i przyjmując perspektywę komparatystyczną, z naciskiem na brytyjskie oraz niemieckie teksty narracyjne i poetyckie. Zamierzam pokazać, w jaki sposób manifestuje się w nich tak interesujący teorię traumy kryzys reprezentacji, w szczególności w powiązaniu z kryzysem języka, który był w literaturze i filozofii podejmowany już na przełomie XIX i XX wieku. Jest to uwaga o tyle istotna, że przywołani przeze mnie autorzy trafili na wojenny front nie jako zawodowi żołnierze, ale jako dobrze wyedukowani ochotnicy i praktykujący (bądź aspirujący) poeci i prozaicy, którzy czytali

\footnotetext{
2 H. Read The Contrary Experience, Faber, London 1963, s. 217.

3 V. Brittain Testament of Youth, Virago, London 1979, s. 143.
} 
dużo literatury. Poszukując słów, którymi można by opisać doświadczenia bitewne, pod wieloma względami całkowicie odmienne od wszystkiego tego, co wcześniej o wojnie słyszeli lub czytali, poddawali też rewizji znaną sobie tradycję literacką. W efekcie zwracali się przeciwko środkom wyrazu, które uznawali za nieadekwatne, oraz proponowali te, które ujmowały doświadczenie wojenne w nowatorski sposób. Należy, jak sądzę, wyciągnąć stąd wniosek, że topos niekomunikowalności tego doświadczenia jest odzwierciedleniem zawiłej relacji, istniejącej z jednej strony między „byciem świadkiem” [witnessing] i „dawaniem świadectwa" [testiffing] o tym, że wojna uprzemysłowiona wiąże się z bezprecedensową przemocą, a zmieniającymi się paradygmatami kulturowymi z drugiej. Pragnę tu pokazać, jak owa relacja została wypowiedziana w reprezentujących różne gatunki utworach angielskich i niemieckich pisarzy okresu I wojny światowej.

Wyrazy „dokument" $i$,świadectwo" stały się metonimiami obejmującymi duży zakres form gatunkowych, które podejmowały kwestię doświadczeń traumatycznych, od różnego rodzaju narracji (wspomnienia, powieści itd.) po poezję. W tej wielości form i środków wyrazu odnajdziemy różnorakie odcienie literackości: narzędzia retoryczne, stylistyczne, figuratywne i performatywne są tu wykorzystywane w odmiennym stopniu. Tym, co wszelako łączy wiele świadectw traumy, jest fakt, że stawiają one, milcząco bądź jawnie, pytanie o granice tego, co da się powiedzieć. Badacze traumy, tacy jak Herman, Caruth, Felman i Laub ${ }^{4}$, podkreślają, że w opowieściach o doświadczeniu traumatycznym pojęcie „dawania świadectwa” niezmiennie charakteryzuje się jednoczesną „niemożliwością" i „koniecznością”, a w konsekwencji - walką między „milczeniem” i poczuciem zobowiązania, by temu doświadczeniu dać wyraz. Paradoks polegający na tym, że trauma domaga się reprezentacji, a jednocześnie zdaje się jej stawiać opór, wymusza kryzys języka, który w literaturze wojennej często wysuwa się na plan pierwszy. Ponieważ doświadczenie traumatyczne jawi się jako szczególnie intensywne

4 Zob.J.L. Herman Przemoc. Uraz psychiczny i powrót do równowagi, przeł. A. i M. Kacmajor, Gdańskie Wydawnictwo Psychologiczne, Gdańsk 1998; C. Caruth Unclaimed Experience: Trauma, Narrative and History, Johns Hopkins University Press, Baltimore-London 1996 - dwa rozdziały tej książki, oba w przekładzie K. Bojarskiej, ukazały się w "Tekstach Drugich" 2010 nr 6 (s. 111-123) i w Antologii studiów nad trauma, red. T. Łysak, Universitas, Kraków 2015 (s. 31-57); Trauma. Explorations in Memory, ed. by C. Caruth, Johns Hopkins University Press, London-Baltimore 1995; S. Felman, D. Laub Testimony: Crises of Witnessing in Literature, Psychoanalysis, and History, Routledge, New York 1992 - zamieszczony tu esej Lauba (Zdarzenie bez świadka: prawda, świadectwo oraz ocalenie, przeł. T. Łysak) ukazał się w „Tekstach Drugich" 2007 nr 5, s. 118-129. 
i trudne do objaśnienia doznanie wewnętrzne, żołnierze wolą milczeć. Dobrej ilustracji dostarcza np. „zmowa milczenia” zawiązana przez okaleczonych weteranów wojennych w wierszu Wilfreda Owena Smile, Smile, Smile [Śmiej się, śmiej się, śmiej]. Mając przed oczami propagandowy tekst, głoszący, że wojna jest konieczna dla podtrzymania „integralności” narodu,

he half-limbed readers did not chafe

But smiled at one another curiously

Like secret men who know their secret safe.

(This is the thing they know and never speak,

That England one by one had fled to France

Not many elsewhere now save under France).

Pictures of these broad smiles appear each week,

And people in whose voice real feeling rings

Say: How they smile! They're happy now, poor things. ${ }^{5}$

[Czytały to kaleki bez najmniejszej złości

Posyłając jedynie znaczące uśmiechy,

Bo jednoczył ich przecież pewien sekret słodki.

(Chociaż wiedzą to dobrze, to nigdy nie zdradzą:

Anglia jeden za drugim pierzchnęła do Francji

I jeśli gdzieś ich szukać, to głównie pod Francją).

Tydzień w tydzień w gazetach ich uśmiech i radość.

A ludzie, w których głosie brzmi prawdziwa troska,

Mówią: Patrz, jak się śmieją! Cudne niebożątka.]

Przeczucie, że słowa nie są godne zaufania, zostało jedynie pogłębione przez propagandę, która wytworzyła dyskursywny kontekst, w jakim tym bardziej uderzająca staje się niezdolność języka do pełnego uchwycenia natury wojennej traumy i życia po traumie oraz do przekazania tego doświadczenia tym, którzy nie walczyli. Próby „opowiedzenia” doświadczenia traumatycznego obarczone są więc dodatkowo ciężarem walki o samookreślenie, ponieważ „ocalali nie tylko musieli przeżyć, aby móc opowiedzieć swoje

5 W. Owen Smile, Smile, Smile [1918], w: Wilfred Owen. The Complete Poems and Fragments, ed. by J. Stallworthy, vol. 1, Chatto \& Windus, The Hogarth Press-Oxford University Press, London 1983 , s. 190. Tytuł wiersza został zaczerpnięty z jednej z najpopularniejszych piosenek marszowych czasu pierwszej wojny "Pack Up Your Troubles in Your Old Kit-Bag, and Smile, Smile, Smile" [Spakuj kłopoty do starego plecaka / I śmiej się, śmiej się, śmiej] (1915). 
historie; musieli także opowiadać historie, aby przeżyć"6. Jak sugerują Caruth, Herman i LaCapra' ${ }^{7}$ opowiadanie traumy jest przesiąknięte dialektyką aprobaty i wyparcia. „Przepracowanie” przeszłości (jak określa to LaCapra), tj. usiłowanie, by odtworzyć „znaczenie" poprzez przypomnienie i odgrywanie traumatycznego doświadczenia, jest wobec tego procesem otwartym, jako że „istotą świadectwa, że się przetrwało, jest nie tylko niezrozumałe powtarzanie przeszłości [...], ale również niezrozumiałość przyszłości, która dopiero ma nadejść"s. Ponieważ proces ten jest nieokreślony, może skutkować wytworzeniem płynnej, „performatywnej” tożsamości - takiej, która nie ma stosownego oparcia w języku, jako że za sprawą owej „płynności” podważone zostaje przekonanie o możliwości mówienia jednolitym, autentycznym, a tym bardziej stanowczym głosem.

Jeśli podejmuje się kwestię przekazu doświadczeń traumatycznych w literaturze I wojny, to należy poczynić rozróżnienie między tymi przypadkami, w których o kryzysie języka mówi się w sposób wyraźny bądź implikowany, i tymi, w których po prostu podkreśla się istnienie "doświadczeniowego" rozejścia się czy zerwania, które następnie może zostać wykorzystane w funkcji krytyki moralnej. Z tą drugą sytuacją mamy np. do czynienia w wierszu Siegfrieda Sassoona Remorse [Skrucha], gdzie przeciwstawia się brutalną wojenną rzeczywistość (w tym przypadku dobijanie bagnetami bezbronnych Niemców) obrazom chwały wytwarzanym przez propagandę: „there's things in war one dare [!] not tell / Poor father sitting safe at home, who reads / Of dying heroes and their deathless deeds" ["są w wojnie rzeczy, których się nie mówi [!] / Ojcu biednemu, co to wie z gazety, / Że w śmierci w bitwie jest jakiś estetyzm"]?. Można to skonfrontować z sytuacjami, w których język faktycznie zawodzi podmiot liryczny czy narratora. Zostaje to albo wyrażone

6 D. LaubZdarzenie bezświadka:prawda, świadectwo oraz ocalenie, przeł. T. Łysak, "Teksty Drugie” $2007 \mathrm{nr}$ 5, s. 120.

7 Zob. C. Caruth Unclaimed Experience; J.L. Herman, Przemoc. Uraz psychiczny i powrót do równowagi; D. LaCapra Writing History, Writing Trauma, Johns Hopkins University Press, Baltimore-London 2001. Jeden z rozdziałów tej ostatniej książki (Pisanie historii, pisanie traumy, przeł. A. Rejniak-Majewska) można znaleźć w tomie Pamięć Shoah. Kulturowe reprezentacje i praktyki upamiętniania, red. T. Majewski, A. Zeidler Janiszewska, Officyna, Łódź 2011, s. 483-512; drugi (Trauma, nieobecność, utrata, przeł. K. Bojarska) w Antologii studiów nad traumq, red. T. Łysak, Universitas, Kraków 2015, s. 59-107.

C. Caruth Literature in the Ashes of History, Johns Hopkins University Press, Baltimore 2013, s. 7. 
wprost, do tego stopnia, że mówiący nie może znaleźć słów na wyrażenie wojny lub może powiedzieć jedynie tyle, że tego się nie da powiedzieć, albo też implikowane w tekście literackim za pomocą językowej fragmentacji, rozpadu spójności narracyjnej bądź ikonicznych reprezentacji ciszy (tak jak w przypadku złamania ostatniego wersetu „Dziwnego spotkania” [Strange Meeting] Wilfreda Owena - więcej o tym utworze powiem później). Jednakże obie sytuacje - przeciwstawianie bezpośredniego doświadczenia doświadczeniu zmediatyzowanemu oraz stwierdzanie faktycznej niemożliwości przekazania tego doświadczenia - są wyrazem zjawiska, które James Campbell określił mianem „wojennego gnostycyzmu”, tzn. uprzywilejowania perspektywy żołnierskiej jako jedynego "prawdziwego" spojrzenia na wojnę, przy jednoczesnym marginalizowaniu, a nawet wykluczaniu innych perspektyw ${ }^{10}$. W szczególności w odniesieniu do literatury I wojny światowej „wojenny gnostycyzm” miał daleko idące konsekwencje, m.in. w utrwaleniu obrazu "poety wojennego" jako jedynego wiarygodnego rzecznika (zdaję sobie sprawę, że w kontekście podjętego przeze mnie tematu jest to sformułowanie paradoksalne) żołnierskiego losu. W tym sensie miał on przemożny wpływ na rozwój kanonu pierwszowojennej poezji, co przez długi czas przekładało się na niemal całkowite pomijanie tekstów pisanych przez nie-żołnierzy, a szczególnie przez kobiety. Doprowadziło to rozpowszechnienia błędnych przekonań, choćby takich, że jedynymi autorami krytycznej, „realistycznej” poezji wojennej byli ci, którzy bitwę widzieli na własne oczy.

Przeświadczenie, że język jest w gruncie rzeczy niezdolny do przekazania okropieństw wojny, pojawiało się w literaturze na długo przed wybuchem I wojny światowej. I istotnie ów topos, odpowiadający temu, co w klasycznej retoryce znane jest jako adynaton albo impossibilia, spotykany jest w tekstach tak dawnych, jak Iliada, czego dowodzi ten okrzyk poety: „Ale mi trudno to wszystko - nie jestem bogiem - wyrazić"11. Jednakże topos niemożności wysłowienia doświadczeń bitewnych, skutkującej oddzieleniem tych, którzy w bitwie brali udział, od tych, którzy udziału nie brali, najbardziej ewidentną postać uzyskał w opisach nowoczesnej wojny zmechanizowanej. W związku z tym stał się przedmiotem wzmożonej uwagi w ramach kulturowo-historycznych badań nad wojną nowożytną, w szczególności w przełomowej, choć kontrowersyjnej książce The Great War and Modern Memory (1975) Paula

10 Por. J. Campbell Combat Gnosticism: The Ideology of First World War Poetry Criticism , „New Literary History" 1999 Vol. 30 No. 1, S. 203-215.

11 Homer lliada, przeł. K. Jeżewska, Prószyński i S-ka, Warszawa 2005, s. 216 (p. XII, w. 175). 
Fussella. W rozdziale zatytułowanym Taktyka wobec innego Fussell podkreśla podziały wytworzone przez I wojnę światową, przede wszystkim między żołnierzami na froncie i cywilami, by następnie przeanalizować dychotomiczny sposób myślenia, jaki w jego przekonaniu jest skutkiem tego podziału. Zdaniem autora, między obiema grupami istniała przepaść, która stała na drodze do osiągnięcia porozumienia: „[...] nawet jeżeli ci, którzy zostali w domach, pragnęli poznać wojenną rzeczywistość, nie byli do tego zdolni, uprzednio jej nie doświadczywszy: warunki, na jakich toczyła się wojna, były zbyt nowe, a jej przemysłowa upiorność całkowicie bezprecedensowa. Wojna była najzwyczajniej czymś niewiarygodnym"12. Od niedawna jednak historycy dość mocno kwestionują stanowisko głoszące niemal całkowity brak interakcji między obiema grupami i podkreślają, że cywile mogli wiedzieć i wiedzieli, „jak straszliwe było życie w okopach”"13; mimo to granica, na którą wskazuje Fussell, i leżące u jej podstaw założenie o deficycie języka w obliczu zdarzeń bitewnych, głęboko zakorzeniły się w kulturowej pamięci wojny.

Bez najmniejszej wątpliwości Fussell trafia w sedno, podkreślając nowość wojny przemysłowej, co poskutkowało, jeśli można tak powiedzieć, nagłą refrakcją i amplifikacją nowoczesności. Wojna - i odnosi się to również do sposobu, w jaki rozumiano język - przyśpieszyła rozwój zjawisk, które były odczuwane już wcześniej. Tak częste w literaturze wojennej podkreślanie, że trudne, jeśli nie niemożliwe, jest znajdowanie słów dla oddania realiów bitwy, wymusiło kryzys reprezentacji językowej, który jeszcze przed wojną został zasygnalizowany w literaturze i myśleniu o języku. Wydarzenia lat 1914-1918 doprowadziły do głębokiej intensyfikacji tego procesu. Dla przykładu, w ostatnich dziesięcioleciach XIX wieku Nietzsche i Bergson odrzucili „realizm semantyczny” i założenie o transparentności języka w stosunku do pozajęzykowej rzeczywistości. Język nie mógł być nośnikiem „prawdy”, skoro - jak twierdził Nietzsche ${ }^{14}$ - był on nieuchronnie metaforyczny i skonwencjonalizowany, a w ujęciu Bergsonowskim był on zjawiskiem, które dzieliło dynamiczny przepływ świadomości na sztywne abstrakcje ${ }^{15}$. W odniesieniu

P. Fussell The Great War and Modern Memory, Oxford University Press, London 1977 [1975], s. 87.

J. Winter Sites of Memory, Sites of Mourning. The Great War in European Cultural History, Cambridge University Press, Cambridge 1995, s. 36.

14 Por. jego esej O prawdzie i kłamstwie w pozamoralnym sensie (Pisma pozostałe, przeł. B. Baran, inter esse, Kraków 2004, s. 160-171), napisany w roku 1873.

Zob. H. Bergson O bezpośrednich danych świadomości, przeł. K. Bobrowska, Aletheia, Warszawa 2016. 
do literatury sceptycyzm wobec języka znalazł doskonały wyraz w napisanym przez Hugo von Hofmannsthala liście fikcyjnego lorda Chandos do jego mentora Franciszka Bacona ${ }^{16}$. Nadawca listu wyraża tutaj swoją rozpacz wobec faktu, że zużyty język nie jest już w stanie porządkować fragmentarycznej rzeczywistości i że świat przedmiotowy mówi do niego w języku, którego nie zna. Ta „wzrastająca nieufność intelektualistów wobec języka”, by użyć słów historyka kultury Modrisa Eksteinsa ${ }^{17}$, została zradykalizowana w czasie wojny, kiedy to zresztą, wraz z pośmiertną publikacją Kursu językoznawstwa ogólnego de Saussure'a (1916), narodziła się lingwistyka strukturalna. W roku 1915 Henry James zauważył, że wojna „nadszarpnęła” i „osłabiła” zasoby językowe: „Wojna zużyła słowa”18.

Na najbardziej oczywistym poziomie rozdźwięk między rzeczywistością wojenną i obrazami wojny rozpowszechnianymi przez propagandę był odczuwany przez coraz większą liczbę osób - nie tylko żołnierzy. W szczególności jednak narastała świadomość, że „tradycyjny język i słownictwo zdawały się nie nadawać do opisu przeżyć w okopach"19. Najbardziej radykalną, psychologiczną i fizjologiczną manifestacją niezdatności języka do sprostania warunkom nowoczesnej wojny była afazja przechodzących traumę żołnierzy bądź - jak zaczęto to wówczas nazywać - ofiar „shell shocku”20 czy „neurastenii”. Trafnie zauważył Walter Benjamin, że w trakcie I wojny światowej żołnierze wracali z pól bitewnych „zredukowani do milczenia", niezdolni do przekazania swoich doznań na linii frontu ${ }^{21}$. Sprzeciwia się to popularnemu założeniu, że

16 Zob. H. von Hofmannsthal List, w: tegoż Księga przyjaciół i szkice wybrane, wyb., przeł. i notami opatrzył P. Hertz, Wydawnictwo Literackie, Kraków 1997, s. 21-36. List został pierwotnie opublikowany w berlińskim „Der Tag” w roku 1902.

17 M. Eksteins Święto wiosny. Wielka wojna i narodziny nowego wieku, przeł. K. Rabińska, PIW, Warszawa 1996, s. 246.

18 H. James Henry James's First Interview, w: Henry James on Culture: Collected Essays on Politics and the American Social Scene, ed. by P.A. Walker, University of Nebraska Press, Lincoln-London 1999, s. 144. M. Eksteins Święto wiosny, s. 246.

20 Zazwyczaj w polskiej literaturze przedmiotu używa się terminu angielskiego. Sporadycznie bywa tłumaczony, np. jako "szok artyleryjski" lub - szerzej - jako "nerwica wojenna” [G.M.].

21 „Czyż nie można było wówczas wygłaszać twierdzeń: ludzie wrócili z pola oniemiali? Nie bogatsi, ubożsi o bezpośrednie doświadczenie". W. Benjamin Doświadczenie i ubóstwo, w: tegoż Twórca jako wytwórca. Eseje i rozprawy, przeł. R. Reszke, KR, Warszawa 2011, s. 401. Benjamin używa tu określenia mitteilbarer Erfahrung; wydaje się, że - szczególnie w kontekście rozważań Löschnigga - lepiej byłoby to oddać jako „doświadczenie, które dałoby się zakomunikować (wysłowić)" albo wprost "doświadczenie komunikacyjne" [G.M.]. 
kryzys wywołuje w ludziach „pęd do narracji” czy wręcz narracyjny przymus i że opowiadanie o traumatycznych zdarzeniach prowadzi do złagodzenia ich negatywnego wpływu na psychikę. W związku z tym można sobie również przypomnieć Freudowskie objaśnienie neurozy jako dokonującego się w teraźniejszości kompulsywnego powtarzania wypartej treści, zamiast - skoro jest wspomnieniem - przekierowania jej w przeszłośćc ${ }^{22}$. Należałoby dodać, że w tym przekierowaniu niepoślednią rolę powinna odgrywać narracja, ta jednak w obliczu wojennej traumy niejednokrotnie zdaje się zawodzić.

Wracając do literatury: wyzwania, jakie nowoczesny konflikt wojenny postawił przed narracją, stoją za zasadniczą ambiwalencją "realistycznej” powieści antywojennej, cechującej się z jednej strony rozmachem dokumentalnym, mającym na celu powiedzenie prawdy o wojnie, przy jednoczesnym dopuszczaniu do głosu przekonania, że takowej „prawdy” nie da się w rzeczywistości wyartykułować. Jakby tego było mało, wojna podważyła pozycję opowiadającego podmiotu. Dyskurs autobiograficzny (a przecież większość tekstów wojennych jest w pewnej mierze autobiograficzna) opiera się na założeniu, że życie jednostki, a także doświadczenia i decyzje, które to życie kształtują, mają jakieś znaczenie. Fakt, że wojna pochłonęła tak wiele ofiar, zdawał się podważać to przekonanie w sposób najbardziej radykalny, podobnie jak czyniło to poczucie przytłoczenia samą skalą wojny i tego, że jest się jedynie trybem w gigantycznej maszynerii.Żołnierze mieli bardzo wątłą, a może nawet zerową wiedzę o tym, jak ich działania są powiązane w szerszej perspektywie, zaś niektóre aspekty walki, takie jak masowe stosowanie materiałów wybuchowych albo typowe dla okopów ograniczenie pola widzenia, nasilały tylko poczucie, że wojna rządzi się swoją własną dynamiką. Wszystko to sprawiało, że naturalny był opór wobec tradycyjnej formy opowiadania, w tym sensie, że pisarze mieli trudność z przekuciem „rozproszonych działań w spójną opowieść o bitwach i kampaniach"23.

W psychohistorycznych badaniach wojny sugerowano, że zmechanizowane konflikty, przez to, że wystawiają żołnierzy na ciągłą sekwencję wstrząsów, znacząco utrudniają narracyjne kodowanie doświadczenia ${ }^{24}$. Chaotyczna

22 "[Pacjent zostaje] raczej zmuszony, by to, co wyparte, powtarzać jako przeżycie współczesne, zamiast [...] przypominać to sobie jako fragment przeszłości". S. Freud Poza zasadq przyjemności, przeł. J. Prokopiuk, PWN, Warszawa 2012, s. 22. 
natura walki zbrojnej wywiera niszczący wpływ na postrzeganie zmysłowe i na umysł, którego integracyjne funkcje są niezbędne do prowadzenia procesów narracyjnych. Dotyczy to zwłaszcza umiejętności chronologicznego porządkowania zdarzeń, która jest niezbędna, jeśli chce się wyrazić doświadczenie $\mathrm{w}$ formie narracyjnej ${ }^{25}$. W warunkach wytworzonych przez front zachodni zawieszeniu ulegały funkcje narracji odpowiedzialne za konstruowanie porządku i znaczenia. Jak stwierdził Samuel Hynes, „pisarz może być świadkiem wojny, ale nie jest mu łatwo wypowiedzieć swoje przeżycia w formie narracyjnej - w opowieści mającej kierunek, związki przyczynowe i klarowne zakończenie - ponieważ byłoby to równoznaczne z nadaniem im sensu, którego nie posiadały bądź nie przejawiały"26.

Dlatego też w niektórych narracjach opowiadających o I wojnie można odnaleźć próby oddania fragmentaryczności żołnierskich przeżyć poprzez zastosowanie, na przykład, poszarpanej składni albo techniki montażu. Zdaniem Davida Williamsa liczne przedstawienia I wojny „rządzą się w znacznej mierze ukrytą epistemologią filmową”, wprowadzającą „kinematograficzną formę pamięci", za której sprawą przeszłość i teraźniejszość zapadają się w „kinematograficznej kondensacji czasu"27. Z użyciem tych technik możemy spotkać się chociażby w Na zachodzie bez zmian Remarque'a (1928/1929) ${ }^{28}$, a także w wielu innych książkach napisanych na przełomie lat 20. i 30., czyli w czasie „boomu powieści wojennej”, np. w Pożegnaniu z bronia Hemingwaya (1929) i w Generals Die in Bed [Generałowie umierają w łóżku] kanadyjskiego pisarza Charlesa Yale'a Harrisona (1930).

Świetnym przykładem stosowania montażu i narracyjnej fragmentaryczności jest powieść Heeresbericht [Doniesienia z frontu] Edlefa Köppena (1930). Chłodnym okiem, a zatem dalece od gwałtownie oskarżycielskiego tonu powieści Remarque'a, przedstawia się tu drogę bohatera od entuzjastycznego

25 Por. B. Hüppauf Der Erste Weltkrieg und die Destruktion von Zeit, w: Geschichte als Literatur. Formen und Grenzen der Repräsentation von Vergangenheit, ed. by H. Eggert, U. Profitlich, K.R. Scherpe, Metzler, Stuttgart 1990, s. 209; 219 (i dalej).

26 S. Hynes A War Imagined: The First World War and English Culture, The Bodley Head, London 1990, s. 106.

D. Williams Media, Memory and the First World War, McGill-Queen's University Press, MontrealKingston 2009, s. 30, 6, 29.

28 Narrator powieści odnotowuje zresztą, że „prawdy” przeżyć frontowych nie można przedstawić w formie narracyjnej: "coś takiego nie może być opowiedziane”. E.M. Remarque Na zachodzie bez zmian, przeł. S. Napierski, Wydawnictwo Dolnośląskie, Wrocław 1999, s. 125. 
ochotnika po pacyfistę uchylającego się od służby wojskowej i zamkniętego w szpitalu psychiatrycznym. Nazwisko Adolfa Reisigera nawiązuje do późnośredniowiecznego słowa oznaczającego „jeźdźca” bądź „kawalerzystę”, a jednocześnie przywołuje na myśl Antona Reisera Karla Philippa Moritza, prototypową XVIII-wieczną powieść rozwojową. Dla bohatera Köppena, pod wieloma względami będącego alter ego autora, doświadczenie wojenne staje się "kształceniem w obrzydzeniu"29, co jest znakiem rozpoznawczym powieści antywojennych z przełomu lat 20. i 30. W tym sensie Heeresbericht to przykład "odwróconego Bildungsroman", opowieści o społecznym wyobcowaniu poprzez doświadczenie wojny, co zresztą znalazło dobry wyraz w tytule wspomnień Roberta Gravesa Wszystkiemu do widzenia! (1929).

Zadeklarowany cel, jaki stawia powieść Köppena, to powiedzenie „prawdy" o wojnie. By to osiągnąć, autor zestawia epizody przedstawiające wojenne losy swojego bohatera z wyimkami z różnych dokumentów: raportów i komunikatów, statystyk, artykułów gazetowych i przemów politycznych. Tematem podejmowanym w Heeresbericht jest w rezultacie rozziew między „rzeczywistością" wojny i przedstawieniami medialnymi, między „autentycznym”, jednostkowym doświadczeniem i totalizującymi, abstrakcyjnymi wizjami polityków i generałów; przede wszystkim jednak za konieczne uznaje się tutaj zbadanie sposobu, w jaki w publicznym dyskursie manipuluje się postawami ludzkimi. Antywojenny utwór Köppena poddaje krytyce wprowadzany przez rządzących "monopol interpretacyjny” $\mathrm{i}$ koryguje propagandę, wykorzystując do tego celu środki relacji indywidualnej, , prywatnego" doniesienia z frontu. Zestawienie i interakcja fikcji (wraz z jej elementami autobiograficznymi) oraz źródeł dokumentalnych prowadzi do paradoksalnego rezultatu: z chwilą, gdy historia Reisigera staje się demaskacją ideologicznych zafałszowań "prawdy" zawartej w dokumentach, czytelnik skłania się ku temu, by opowieść tę uznać za pogłębioną "prawdę” wojny. Z tego względu źródła dokumentalne wzmacniają w istocie rzeczy zgłaszane przez fikcję roszczenie do prawdziwości.

Choć wojskowa kariera Reisigera rozwija się zgodnie z chronologią linearną, to jednak „kondensacja czasu”, wynikająca z rozbicia na epizody i nieprzerwanego używania czasu teraźniejszego, sprawia, że zdarzenia zdają się zrywać z chronologicznej kotwicy. Zyskują one jednak pewną tematyczną jedność pod postacią typowych sekwencji z pola walki. W rezultacie bitewny

29 D. Trotter The British Novel and the War, w: The Cambridge Companion to the Literature of the First World War, ed. by V. Sherry, Cambridge University Press, Cambridge 2005, s. 40. 
chaos jest relacjonowany za pomocą ostrych filmowych cięć - tak jak w poniższym opisie natarcia:

Wie der letzte Rauch sich vom Boden gelöst hat, steht und liegt und kniet und kriecht und läuft und springt, graue lebendige Masse; der Feind. Und stürmt, Handgranaten hochgeschwungen, das Bajonett gereckt, gegen den Graben vor.

Da kläfft das Maschinengewehr neben Reisiger los. Da prasselt neben ihm Schnellfeuer aller Gewehre.

Herrgott, was geschieht! Dutzende von Franzosen werfen die Arme hoch und fallen rücklings zur Erde. Aber andere Dutzende dicht geballt drängen weiter vorwärts.

Die Feuer der Handgranaten zischen. Die Flammen der Artillerie rasen. Und: Franzosen, immer wieder neu: Franzosen: vorwärts.

Am Maschinengewehr schreit man durcheinander. Reisiger begreift kein Wort. ${ }^{30}$

[Gdy z ziemi wreszcie podniósł się ostatni dym, stoi i leży i klęczy i pełza i biegnie i skacze, szara żywa masa, wróg. I naciera, granaty w górze, bagnety na sztorc, wprost na nasze okopy.

A wtedy karabin maszynowy przy Reisigerze zaczyna odszczekiwać. Zewsząd prędki ogień z wszystkich luf.

Dobry Boże, co się dzieje! Dziesiątki Francuzów wyrzucają w górę ręce i pokotem padają na ziemię. Lecz dziesiątki innych, gęsto skupione, nadal suną naprzód.

Syczy ogień ręcznych granatów. Mkną płomienie artylerii. I: Francuzi, wciąż nowi Francuzi: prą na nas.

Przy karabinie maszynowym bezładne krzyki. Reisiger nie rozumie ani słowa.]

Powieść Köppena jest dobrą ilustracją tezy głoszonej przez Cathy Caruth, że „traumy nie da się zlokalizować w jakimś jednostkowym, gwałtownym lub źródłowym wydarzeniu z przeszłości, co raczej w sposobie, w jaki nieprzyswojona natura tego zdarzenia [...] powraca, by następnie prześladować tego, który przeżyl"31. Technika narracyjna jest tu odpowiedzią na problem przed-

\footnotetext{
30 E. Köppen Heeresbericht, Rowohlt, Reinbek bei Hamburg 1979, s. 79-80.

C. Caruth Unclaimed Experience, s. 4.
} 
stawienia przemijających (albo „nieprzyswojonych”) wydarzeń pod postacią trwałej konfiguracji temporalnej, a także na zachodzącą w akcie opowiadania kwestię mediacji między wieloma epizodami i jednolitą historią. Zamiast jednak ujmować zdarzenia w spójną narrację, powieść Köppena posługuje się środkami filmowymi. Chodzi tu nie tylko o posiłkowanie się montażem, ale także o wytworzenie „kinematograficznej” bezpośredniości poprzez stosowanie czasu teraźniejszego; jednocześnie narracja przyjmuje wielorakie perspektywy, które, jeśli można tak się wyrazić, pełnią funkcję „soczewek” nakładanych na zdarzenia. Analogie filmowe stają się ewidentne w scenie opisującej urlop Reisigera, trafnie zresztą przedstawiającej rozziew między cywilami i ludźmi z frontu. Gdy wraca na wojnę, wspomnienia domu rozwijają się przed jego oczami jak film: „zu schnell gedreht, ungeschickt geschnitten, [...] zu Bildchen, zu Fetzen zerrissen" [„zbyt spiesznie kręcony, niezgrabnie pocięty, [...] rozbity na klatki, na strzępki"] ${ }^{32}$. Filmowa stylistyka rwącej się taśmy zyskuje tu szczególne znaczenie, bo niczym w przerwanej projekcji kinowej, struktury sensotwórcze odmawiają posłuszeństwa w obliczu wojny: "Nur Verstehen gibt es nicht mehr, gibt es nicht mehr. [...] Der Motor hakt, röchelt, spuckt, setzt aus” [„Tylko rozumienia już nie ma, po prostu nie ma. [...] Silnik trajkocze, sapie, pluje, traci oddech"] ${ }^{33}$.

Fragmentacja i dezintegracja głosu narratorskiego w powieści Köppena są odzwierciedleniem przekonania, że „prawdziwy” charakter doświadczenia wojennego jest niemożliwy do przekazania tym, którzy go nie podzielają. Jednakże zerwanie z linearnością, wytworzona przez stosowaną w książce technikę montażu wielość punktów widzenia, a także - w wyniku ich skonfrontowania - wzajemne relatywizowanie tego, co dokumentalne i fikcjonalne, również prowadzą do zatarcia różnicy między „faktycznością” i „fikcjonalnością". Przeżycia bohatera, nawiązujące w znacznej mierze do doświadczeń autora, są prezentowane w Heeresbericht na zasadzie przeciwstawienia "faktu” i „fikcji”, tego, co przydarzyło się „Reisigerowi” (i co poznajemy za sprawą narracji heterodiegetycznej), i tego, co może powiedzieć sam Köppen (inaczej rzecz ujmując, jego „literacka”, uosobiona w alter ego, rekonfiguracja rzeczywistości).W swoich studiach nad traumą i autobiograficznością Leigh Gilmore odwołuje się do „długiej tradycji autobiograficznej, polegającej na przedstawianiu własnej osoby jako całkowicie wyjątkowej i, z tego właśnie powodu, potrafiącej mówić w imieniu innych, co realizuje 
się poprzez introspekcję i obnażenie się". Badaczka stwierdza następnie, że ten "paradoks przedstawienia" zostaje wzmocniony, ,gdy autoreprezentacja pociąga za sobą przedstawienie traumy"34. Choć utratę złudzeń, jaka staje się udziałem Reisigera, można uznać za typowe dla fabuł wojennych, to jednakowoż na innym poziomie mamy tu do czynienia z głęboko osobistą, podjętą przez autora próbą uporania się z własnymi frontowymi przeżyciami.

Narracja w Heeresbericht przeciwstawia się trwałej, jednoznacznej identyfikacji i daje do zrozumienia, że traumatyczne przeżycia bohatera nie mogą być opowiedziane w sposób konwencjonalny, a jedynie poprzez nielinearność, fragmentację i „performatywność" powieściowego języka, biorącą się z metaforyzacji i wzajemnego oddziaływania różnych tekstów. Wynikająca z wielości głosów pluralistyczna struktura tekstu kieruje uwagę czytelnika ku problemowi konstytuowania doświadczenia i jego możliwej mediatyzacji. W związku z tym wyrwy w opowiadaniu Köppena zaczynają działać jak przejaw hiperrealizmu, który - w odniesieniu do zdarzeń traumatycznych - jest mimetycznie skuteczny właśnie dzięki temu, że ogranicza sygnifikację i te wymiary narracji, które odpowiadają za tworzenie sensu (spójność, teleologia, przyczynowość) przy jednoczesnym faworyzowaniu niekoherentności i zmysłowej bezpośredniości. I faktycznie, o czym zresztą przekonywała Anne Whitehead w swoich badaniach poświęconych napięciu między traumatycznymi zdarzeniami a ich przedstawieniem, „opowieść o traumie" może skutecznie rozwiązać konflikt traumy i reprezentacji, gdy stara się przedstawić empiryczną specyfikę zdarzenia traumatycznego w taki sposób, by dać wyobrażenie o zakłóceniach i przesunięciach doświadczanych przez przeżywający, odtwarzający i wspominający podmiot ${ }^{35}$. Eksperymenty narracyjne w Heeresbericht dowodzą zatem, że Köppen miał świadomość ograniczeń, jakie wiążą się z pojęciem reprezentacji i które wskutek rozbicia integralności mówiącego podmiotu prowadzą do podważenia pojęć „faktyczności” i „autentyczności”: „autentyczność aktu opowiadania jest ściśle powiązana z prawdomównością narratorskiego głosu: jeśli integralność tego ostatniego jest zagrożona, bo jego pamięci nie można już ufać, np. w wyniku [...] traumy, to sama narracja traci walor prawdziwości”36. W powieści Köppena próbuje się przywrócić „prawdomówność” poprzez

L. Gilmore The Limits of Autobiography. Trauma and Testimony, Cornell University Press, Ithaca 2001, s. 19. Zob. A. Whitehead Trauma Fiction, Edinburgh University Press, Edinburgh 2004.

36 J. Straub Introduction: The Paradoxes of Authenticity, w: Paradoxes of Authenticity: Studies on a Critical Concept, ed. by J. Straub, transcript, Bielefeld 2012, s. 22. Związki "pamięci” i "traumy” 
zdyskredytowanie spójności narracyjnej i mimetyczne ujęcie fragmentacji i nieładu. Efekt ten uzyskuje się również poprzez „filmową” bezpośredniość, która skutkuje przesłonięciem integrującej funkcji narracyjnego głosu (i jego oparcia w pamięci), skierowana jest bowiem na quasi-dramatyczne odtworzenie traumatycznego doświadczenia.

Podobnie jak w tekstach narracyjnych, kryzys przedstawienia wywołany przez wojnę zmechanizowaną znalazł też swój wyraz w poezji. Dla przykładu, poświęcone wojnie wiersze niemieckiego ekspresjonisty Augusta Stramma stawiają sobie za cel, by doświadczenie nowoczesnej wojny ująć w formie eksperymentu formalnego. Fragmentaryczna składnia i zacieranie granic leksykalnych, a także rytmiczne staccato będące efektem asyndetycznego rozmieszczenia skrawków słów są lustrzanym odbiciem chaotycznej natury przeżyć na froncie. Warto w tym kontekście zwrócić uwagę na wiersz Natarcie [Sturmangriff]:

Aus allen Winkeln gellen Fürchte Wollen

Kreisch

Peitscht

Das Leben

Vor

Sich

Her

Den keuchen Tod

Die Himmel fetzen.

Blinde schlächtert wildum das Entsetzen.

Ze wszystkich kątów wyją lęki życzenia

Wrzask

Smaga

Życie

Przed

Sobą

wymagają tu szczególnej uwagi. lan Hacking wskazywał, że rosnące od końca XIX wieku zainteresowanie pamięcią odpowiadało czasowo kluczowemu przesunięciu w rozumieniu traumy jako defektu "fizycznego czy fizjologicznego" ku traumie jako „ranie w duszy”. I. Hacking Rewriting the Soul. Multiple Personality and the Sciences of Memory, Princeton University Press, Princeton 1995, s. 4. W efekcie "pamięć miała odtąd oznaczać miejsce, w którym ta rana była zdeponowana" (L. Gilmore The Limits of Autobiography, s. 32). 
$\mathrm{Tu}$

Dysząca śmierć

Niebiosa w strzępach

Ślepo masakruje dzika zgroza. ${ }^{37}$

Wrażenie chaosu bitewnego uzyskuje się tu metodą ekstremalnej lingwistycznej kondensacji i rewitalizacji języka poetyckiego poprzez łamanie składni, złożenia („wildum”) i leksykalne dwuznaczności.I tak „Blinde” może być zarówno rzeczownikiem w bierniku („ślepców”), jak i przysłówkiem, tak jak w przekładzie polskim, zaś „Fürchte” może być jednocześnie gramatyczną transformacją czasownika „fürchten” („bać się") albo liczbą mnogą od rzeczownika „Furcht”, która to forma liczby mnogiej w języku niemieckim jednak nie występuje.

Jako kapitan rezerwy, Stramm został niezwłocznie powołany do wojska wraz z wybuchem wojny, pełniąc służbę na froncie zachodnim oraz w Galicji, gdzie przebywał od końca kwietnia do 1 września 1915 roku, dnia swojej śmierci na polu walki. Pobyt na froncie jedynie pogłębił bolesne poczucie rozdwojenia między radykalnym rozumieniem siebie jako artysty oraz karierą oficera rezerwy i urzędnika (Stramm, posiadacz doktoratu, był inspektorem pocztowym). Jako żołnierz wielokrotnie nagradzany za odwagę, jako poeta potępiał wojnę $e^{38}$.

Technika poetycka Stramma, co wynika z traumatycznych doświadczeń na polu walki, jest wyrazem "utraty głosu, życia, wiedzy, świadomości, prawdy, zdolności odczuwania, zdolności mowy" ${ }^{39}$. Skutkuje to stłumieniem autorskiej podmiotowości, co może być też w pełni świadomym sposobem obejścia dylematu, przed którym stoją sprzeczne żądania poety i żołnierza. I rzeczywiście wśród wojennych wierszy Stramma tylko w jednym, zatytułowanym Angststurm [Burza lęku] ${ }^{40}$, pojawia się „ja" - we wszystkich pozostałych pod-

37 A. Stramm Sturmangriff/ Natarcie, w: tegoż Ludzkość i inne wiersze, wstęp, wyb. i przeł. L. Szaruga, Oficyna Wydawnicza Volumen, Warszawa 2018, s. 78-79.

38 W posłowiu do przygotowanego przez siebie wydania dzieł poetyckich Stramma Jeremy Adler wspomina o "dziwnie rozdwojonym życiu” ("eigentümliches Doppelleben”), które w tamtym czasie musiał prowadzić poeta. A. Stramm Die Dichtungen. Sämtliche Gedichte, Dramen, Prosa, ed. J. Adler, Piper, Münich 1990, s. 370.

S. Felman The Return of the Voice: Claude Lanzmann's Shoah, w: Felman and Laub Testimony. Crises of Witnessing in Literature, Psychoanalysis, and History, s. 231.

40 Zbiór przygotowany przez L. Szarugę nie zawiera tego tekstu; nie znalazłem też żadnego innego tłumaczenia polskiego [G.M.]. 
miot wycofuje się poza quasi-obiektywny opis walki, w którym głos samego poety ulega całkowitemu wyciszeniu:

Wo sind Worte für das Erleben? [...] Das Wort schon stockt mir vor Grauen. [...] Ich dichte nicht mehr, alles ist Gedicht umher. Elendes feiges heimtückisches Grausen und die Luft kichert höhnisch dazu und gurgelt donnernd von den Bergen her ...

[Gdzież są słowa na to doświadczenie? Słowo zawodzi wobec tej zgrozy. [...] Nie piszę już wierszy, wszystko wokół jest poezją. Nędzna, tchórzliwa, podstępna zgroza i powietrze szyderczo chichocze i grzmotem uderza z gór...]

[...] ein Grauen ist um mich wallt wogt umher, erwürgt verstrickt, es ist nicht mehr rauszufinden. Entsetzlich. Ich habe kein Wort. Ich kenne kein Wort.

[[...] wokół mnie kłębi się zgroza, dusząca mnie i oplatająca, nie ma drogi ucieczki. Przerażające. Nie mam słowa. Nie znam żadnego słowa. $]^{41}$

Milczenie i wymazanie poetyckiej jaźni to w wojennej twórczości Stramma świadectwa dylematu związanego z traumą, a mianowicie faktu, że traumatyczne zdarzenie wymaga zintegrowania z życiem i tożsamością jednostki, a jednocześnie może być tak, że całościowy sens tego zdarzenia nigdy nie zostanie zrozumiany. Usiłowanie przedstawienia traumatycznych doświadczeń jedynie wyostrza tę sytuację: jeżeli przedstawienie indywidualnego doświadczenia wiąże się z traumą, to próba dostarczenia literackiego świadectwa zostanie utrudniona przez zrelatywizowanie pojęcia "autentyczności" i wytworzenie podmiotu, którego cechą konstytutywną są ograniczenia w konstruowaniu „autentycznych" czy nawet „obiektywnych” przedstawień (siebie). Werbalny minimalizm Stramma jest odwróceniem zaproponowanego przez Kristevą pojęcia podmiotu, którego ewolucja sprzęgnięta jest z ewolucją języka („le sujet en procès”) ${ }^{42}$. Mamy tu raczej do czynienia z pod-

Listy do Herwartha Waldena (6 października 1914 roku) i do Herwartha i Nell Waldenów (14 lutego 1915 roku), cytowane w: Literatur-Revolution 1910-1925. Dokumente, Manifeste, Programme, ed. by P. Pörtner, vol. 1: Zur Ästhetik und Poetik, Luchterhand, Darmstadt 1960, s. 47, 50. 
miotem wycofującym się wobec przytłaczającej przemocy, tłumiącej wszelką indywidualną wypowiedź.

Awangardowa poezja w rodzaju tej, jaką tworzył Stramm oraz inni poeci skupieni wokół ekspresjonistycznego periodyku „Der Sturm” (1910-1932), redagowanego przez Herwartha Waldena, jest praktycznie nieobecna w brytyjskiej literaturze wojennej. Nie oznacza to jednak, jak zresztą wynika z przytoczonych na początku tekstów, że brytyjscy autorzy nie przejmowali się problemem językowego wyrażania natury wojennych przeżyć. Godnego uwagi przykładu dostarcza w tym kontekście wiersz Wilfreda Owena Dziwne spotkanie, w którym przedstawiono konflikt między pragnieniem zapomnienia tego, z czym zmierzenie się byłoby zbyt bolesne, a dążeniem do tego, by pamiętali inni, by została wyartykułowana, jak to określa poeta, „niewypowiedziana prawda" o wojnie. Jednakże ta prawda nie jest, by posłużyć się słowami Desmonda Grahama, „jedną jedyną prawdą wojny, lecz złożoną prawdą naszych doznań i emocji”“33. Wiersz jest streszczeniem sennej wizji: podmiot liryczny wkracza do podziemnego świata, by spotkać na swej drodze ducha wroga, którego wcześniej zabił na polu walki. Ów „inny” okazuje się być alter ego poety, miał bowiem artystyczne ambicje, które przerwała nagła śmierć: „Cokolwiek, bracie, było twą nadzieją, / Było nadzieją i mojego życia"44. Dziwne spotkanie jest zatem refleksją nad rolą poety w czasie wojny, a „zasadniczym problemem tekstu jest los poetyckiego oglądu świata" ${ }^{\text {. }}$. Podobnie jak wiersze i listy Augusta Stramma, Dziwne spotkanie dobrze oddaje rozterki Owena wynikające z podwójnej roli żołnierza i poety, w utworze tym bowiem wykorzystuje się romantyczne rozumienie poety jako proroka i odkupiciela, niosącego światu "prawdę" i pocieszenie:

Then, when much blood had clogged their chariot-wheels

I would go up and wash them from sweet wells,

Even with truths that lie too deep for taint.

$[\ldots]$

D. Graham The Truth of War: Owen, Blunden, Rosenberg, Carcanet, Manchester 1984, s. 77.

44 W. Owen Dziwne spotkanie, przeł. J. Wittlin, w: Czas niepokoju. Antologia współczesnej poezji brytyjskiej i amerykańskiej, wyb. i oprac. P. Majewski, Perspectives in Culture, Nowy Jork 1965, s. 142. Inny przekład tego wiersza, autorstwa E. Życieńskiej, można znaleźć w "Literaturze na Świecie" $1983 \mathrm{nr} 2$, s. 306-307.

45 M. Rawlinson Wilfred Owen, w: The Oxford Handbook of British and Irish War Poetry, ed. by T. Kendall, Oxford University Press, Oxford 2007, s. 129. 
I am the enemy you killed, my friend.

I knew you in this dark; for so you frowned

Yesterday through me as you jabbed and killed.

I parried; but my hands were loath and cold.

Let us sleep now...

A gdyby krwi zakrzepło już za wiele

Na kołach ich rydwanów, ja bym ruszył, aby

Obmyć te koła, z słodkich czerpiąc krynic,

Obmyć je chociaż takimi prawdami,

Co w tak niezmiernych biją głębokościach,

Że brud ich żaden tam już nie dosięże.

[...]

Jam wróg, któregoś ty zabił, mój bracie.

Poznałem cię w tej śmierci, bo tak się skrzywiłeś

Wczoraj - przeze mnie - gdyś dźgał, gdyś zabijał.

Jam odparował cios, lecz moje ręce

Były ospałe i zimne. A teraz

Śpijmy... ${ }^{46}$

Werset „Jam wróg, któregoś ty zabił, mój bracie” oferuje wizję pojednania, kryje się tu bowiem sugestia, że obaj „wrogowie” byli w istocie połączeni duchową jednością ${ }^{47}$. Zabijając swoje alter ego, liryczne „ja” zabiło w gruncie rzeczy swoją własną poetycką jaźń. W czasie wojny głos poetycki musi ostatecznie zamilknąć. W związku z tym ostatni werset jest niekompletny; załamuje się po tym, jak cztery monosylabiczne słowa zakłóciły rytmiczny puls jambów, stając się ikonicznym odzwierciedleniem milczenia „śpiących" (tj. ofiar wojny), na których wiersz się kończy.

W utworze Owena wymiana zdań między żołnierzem-poetą i jego drugim „ja” prowadzi do wykreowania intersubiektywnego wymiaru, który jednocześnie zaczyna obejmować czytelnika. Dzięki temu wymiarowi wiersz Owena staje się sprawdzianem zdolności podmiotu do wywołania

46 W. Owen Dziwne spotkanie, s. 142-143.

47 W brulionowej wersji tekstu linijka ta brzmi następująco: „I was a German conscript, and your friend" ["Byłem niemieckim rekrutem i twoim przyjacielem"]. W. Owen The Complete Poems and Fragments, ed. by J. Stallworthy, vol. 2, Chatto \& Windus, London 1983, s. 307. 
„współodczuwalności” [response-ability $]^{48} \mathrm{u}$ innych, posługując się w tym celu skutecznym manewrem, jakim jest nieumiejętność podmiotu mówiącego, by w pełni wyrazić („Zdawało mi się [!], że uciekłem z bitwy”49, w. 1) swoje doświadczenie. Utwór kreuje narkotyczny świat snu, co w połączeniu z kończącym wiersz milczeniem sprawia, że czytelnik nie może przesadnie polegać na przedstawieniu realności żołnierskiego cierpienia - choć tekst nadal może dawać poczucie "apatii, moralnej albo emocjonalnej znieczulicy" pełny wymiar tego cierpienia nie może zostać uchwycony.„Współodczuwalność" (albo „empatyczny niepokój”, by użyć określenia LaCapry) uzyskuje się zatem nie poprzez postawienie na pierwszym planie indywidualnego (traumatycznego) doświadczenia, ale przez subtelne odwołanie, za pośrednictwem wytworzonego przez poezję „innego”, do czytelnika - w taki sposób, że jego empatii „towarzyszy szacunek dla drugiej osoby i świadomość, że jej doświadczenie nie jest naszym własnym"51. Pytanie, jak połączyć traumatyczne doświadczenie wojny z trajektorią życia poety - Stramm odpowiadał na to pytanie skrajnym redukcjonizmem - przejawia się tutaj w dwoistości mówiącego podmiotu i wroga/przyjaciela. Skutek jest taki,że „prawdomówność” wiersza polega na zwróceniu się do czytelnika, by imaginacyjnie podzielał to, czego nie może podzielać w realnym życiu. Jak podkreślał Desmond Graham, poezja Owena stawia sobie za cel, by „pośredniczyć między doświadczeniem wojennym i naszą niewiedzą"52.

Jak już wskazywałem, trauma oraz wywoływany przez nią kryzys językowej reprezentacji są nierozerwalnie związane z nowoczesnością pierwszowojennego pisarstwa i stosowanych w nim technik, zwłaszcza tych, które historycy literatury określają mianem „modernistycznych", takich jak fragmentaryczność narracji i (multi) perspektywizm, a także poetycki „redukcjonizm”. Literatura I wojny światowej jest miejscem negocjacji, przewartościowania oraz ponownego zdefiniowania świata sprzed wojny. Paul Fussell określa ten świat mianem „statycznego", takiego, w którym „wartości jawiły się jako stabilne

48 Termin Kelly Oliver, zaproponowany w książce Witnessing Beyond Recognition, University of Minnesota Press, Minneapolis 2001.

49 W. Owen Dziwne spotkanie, s. 141.

S. Sontag Widok cudzego cierpienia, przeł. S. Magala, Karakter, Kraków 2010, S. 122. Choć autorka interesuje się głównie wizualnymi przedstawieniami przemocy we współczesnych mediach, to jej przemyślenia zdają się zasadne również w przypadku poezji wojennej.

D. Graham The Truth of War, s. 65. 
i w którym znaczenia rzeczy abstrakcyjnych zdawały się trwałe i wiarygodne"53. Jego spojrzenie na wojnę jako cezurę między tradycją i nowoczesnością zostało jednak zakwestionowane przez historyków kultury, takich jak np. Jay Winter czy Eric Hobsbawm ${ }^{54}$, zaś sens relacji łączącej Wielką Wojnę i nowoczesność pozostaje przedmiotem dyskusji. Istnieje mimo to zgoda co do faktu, że wojna przyspieszyła zjawiska rozwojowe, które istniały już przed rokiem $1914^{55}$, a także iż objęła, jak ujął to Dan Todman, „,ałe mnóstwo napięć tkwiących w nowoczesnym świecie - między technologią i ludzkością, państwem i jednostką oraz tradycją i postępem"56.

W nowych okolicznościach walki frontowej podczas I wojny, „słuszność poprzednich kategorii uległa dezintegracji" "57. Dotyczy to w szczególności myślenia o języku, którego wartość jako środka reprezentacji została, jak się wydaje, gruntownie zrewidowana w wyniku doświadczenia uprzemysłowionej wojny.

W niniejszym tekście badałem topos niewyrażalności i niemożności przekazania wojennego doświadczenia, odwołując się przy tym do podkreślanego przez teorię traumy przekonania o kryzysie reprezentacji wywołanym przez traumę; próbowałem pokazać, jak ten impas może być zestawiony z przedwojennym sceptycyzmem wobec języka, sceptycyzmem, który nadał kształt całemu pisarstwu nowoczesnemu i modernistycznemu. Literatura I wojny jest świadectwem faktu, że „siła języka jako ogólnonarodowego medium [...] [oraz] spoiwa nadającego ludziom głębokie poczucie jedności" ${ }^{58}$ okazała się zwodnicza, żołnierze bowiem uznawali, że ich doznania są trudne czy wręcz niemożliwe do przekazania, cywile zaś, wedle określenia Roberta Gravesa,

P. Fussell The Great War and Modern Memory, s. 21.

54 Por. J. Winter Sites of Memory, Sites of Mourning; E. Hobsbawm Wiek skrajności. Spojrzenie na krótkie dwudzieste stulecie, przeł. J. Kalinowska-Król, M. Król, Politeja, Warszawa 1999, s. 181: "Mimo szoku wywołanego pierwszą wojną światową kontynuacja nie została w tak oczywisty sposób przerwana, aż do lat trzydziestych - dekady Wielkiego Kryzysu, faszyzmu i nadciągającej wojny". Por. np. J.-M. Rabaté 1913: The Cradle ofModernism, Blackwell Publishing, Malden-Oxford 2007.

D. Todman The First World War in Contemporary British Popular Culture, w: Untold War. New Perspectives in First World War Studies, ed. by H. Jones, J. O'Brien, C. Schmidt-Supprian, Brill, Leiden-Boston 2008, s. 436. 
„mówili w języku obcym”"59. Jednakże w przeświadczeniu, że okropieństwa wojny nie mogą zostać ujęte w słowa, krył się również potężny potencjał ekspresji. Kate McLoughlin wyraziła to następująco: „nieznajdowanie słów, by opisać wojnę - lub przynajmniej zaręczanie, że nie można ich znaleźć - to być może najlepsza z technik, dzięki którym można ukazać jej ogromną skalę"60.

Przełożyt Grzegorz Marzec

\section{Abstract}

\section{Martin Löschnigg}

UNIVERSITY OF GRAZ

Lacking Words for War: Trauma and the 'Crisis of Language' in English and German Literature about World War I

Löschnigg investigates a widespread topos in literary representations of World War I, namely the idea that the 'true' nature of the war experience could not be expressed and, above all, that it could not be communicated to civilians. Drawing on English and German examples - especially works by poets Wilfred Owen and August Stramm and by novelist Edlef Köppen - he analyses this topos in different genres. He also demonstrates how it reflects the representational impasse emphasized by trauma theory as well as the'crisis of language' underlying (literary) modernity.

\section{Keywords}

First World War literature, trauma, incommunicability, crisis of language, modernity

Pełne zdanie brzmi u Gravesa następująco: „The civilians talked a foreign language; and it was newspaper language"; w polskim przekładzie (R. Graves Wszystkiemu do widzenia, przeł. T. Wyżyński, Książka i Wiedza, Warszawa 1991, s. 193) zagubił się istotny dla Löschnigga sens: „Cywilom nie schodziły z ust gazetowe slogany" [G.M.].

60 K. McLoughlin War and Words, w: The Cambridge Companion to War Writing, ed. by K. McLoughlin, Cambridge University Press, Cambridge 2008, s. 22. 